\title{
Islamic Education and Social Transformation: Teenager Corruption Watch (TCW) Modelling in Islamic School
}

\author{
Mukodi \\ High Education and Educational Sciences (STKIP) PGRI Pacitan \\ mukodi@yahoo.com
}

\begin{abstract}
Nowadays, corruption is one of Indonesia's acute problems. It seems to have infected and spread to everyone. It influences every aspect of human lives and social elements. Therefore, it ruins the human civilization. The nation's basis and nations'strength become weak. The researcher used descriptive qualitative survey method to explain how Teenager Corruption Watch (TCW) modeling overcomes the corruption problems early in this country. The research's results are as follows: first, Islamic insight (Islamic transformative) can be used effectively as a basic point in implementing TCW in Islamic schools. Second, the existence of TCW can be an organization for anti rasyuwah in Islamic schools. Third, the TCW model in Islamic schools consists of three forms, such as (a) TCW-based extracurricular, (b) TCW-based intracurricular, and (c) top-down applicative TCW.
\end{abstract}

Keywords: Islamic education, social transformation, Islamic school

\section{Introduction}

Crucial problems in Indonesia are still dominated by Islamic identity, social inequality and corruption 1 . A series of demonstrations in Jakarta and other areas lately is actually a reflection of those three problems above. Islamic identity is exposed to 'endless' conflict. The conflict happens between moderate Islam and radical Islam. It is also between

\footnotetext{
${ }^{1}$ In Islam, corruption is often relatedto the word ghulûl. Ghulûl is lexically interpreted as akhdh al-shay 'wadassuhûfimatô'ihi, which means taking something and hiding it in their own property. In Islamic history, ghulûl terminology arises because there is war spoils embezzlement before being distributed. Besides, there is also a term called rishwah which means commissions, rewards, wages, and gifts, or bribery.In addition, QS. AlMâi'dah [5]: 38, pointsout to the problem of ghasab and saraqa. Ghasabis taking something from others by coercion and saraqa is the behavior of taking the other's treasures secretly, and there are still many verses of the Qur'ân that write about corruption in a broad sense. Read, AzumardiAzra, "Agama danPemberantasanKorupsi", dalamHarmanto,

"PendidikanAntikorupsiMelaluiBudayaSekolahBerbasisNilaiNilaiKeislaman," JurnalIslamica, Vol. 7, No. 1, 2012, h. 101-102.
}

AJIS : Academic Journal of Islamic Studies vol. 4, no. 2, 2019

IAIN Curup - Bengkulu | p-ISSN 2580-3174, e-ISSN 2580-3190

Available online: http://journal.staincurup.ac.id/index.php/AJIS 
Left Islam versus right Islam. In addition, it also happens between obedient Islam (santri) vis a vis disobedient Islam (abangan), and many others. Tragically, the symbol of Islamic identity 'is brought', to practical politics in some areas.

The Jakarta Governor Election case is empirical of it. The conflict of religious identity between Islam and non-Islam arises. Anis Baswedan is positioned as an Islamic leader candidate and Basuki Cahaya Purnama (Ahok) is a potential non-Muslim leader. Both are fighting each other. As a result, the grassroots communities are ignited.2 Wahid Institute's record puts Basuki Tjahaya Purnama-alias Ahok-become the most violated individual by state and non-state parties of people. He is assumed heretical. Ahok has 4 actions from state parties and 10 actions by non-state parties. 3 The case of a massive demonstration of 411, 212, 313, and 299 in Jakarta are the authentic proof of that incident. Fortunately, the demonstration runs peacefully and safe.

On the other hand, social inequality, between the rich and the poor lately is brought into reality. Nearly 170 million people (or equivalent to nearly $70 \%$ of the total population) is categorized as Upper-middle class people in 2015.4 Meanwhile, the poor or (dhuafa') consists of 27.76 million people (10.70 percent) as in September 2016. It decreased by 0.25 million people compared to March 2016 of 28.01 million people (10.86 percent).5 Unfortunately, the Indonesian economy is only dominated by some particular people.

\footnotetext{
${ }^{2}$ The conflict between them is essentially set as part of a political strategy. Religious issues were played to gain votes. Finally, the people of DKI in particular, and Indonesian society, in general, are polarized into two, Islam and non-Islam. As a result, the face of Islam represented by Anis-Sandi wins over Ahok-Jarot. Later, Ahok was finally imprisoned on charges of Islam abuses. See, Dian Andryanto, "Ahok Dihukum Dua Tahun, Putusan Hakim Bulat," https://nasional.tempo.co/read/873676/ahok-dihukum-dua-tahunputusan-hakim-bulat.

${ }^{3}$ Penyusun, T. (2016). Ringkasan Eksekutif Laporan Kemerdekaan Beragama Berkeyakinan (KBB) Di Indonesia Tahun 2016. (Jakarta: Wahid Foundation, 2016),h.16.

${ }^{4}$ Anonim, "Kelas Menengah Di Indonesia Mencapai 170 Juta Pada Tahun 2015," http://kbriseoul.kr/kbriseoul/index.php/id/2013-01-21-22-49-05/berita-terkini/419kelas-menengah-di-indonesia-mencapai-170-juta-pada-tahun-2015.

5Public Relations, "BPS: As of September 2016, the number of Indonesian Poor Reduced 0.25Million, "http://setkab.go.id/bps-per-september-2016-jumlah-pendudukmiskin-indonesia-bekurang-025- million/."
} 
However, the Oxfam organization states that the total wealth of the four richest people in Indonesia, which recorded to 25 billion US dollars, is equivalent to the wealth of the 100 million poorest people. In its report, Oxfam declares that the wealth of the four richest billionaires in Indonesia is higher than the total wealth of 40 percent of the poor people or about 100 million people. Indonesia is in the top six countries with the wide economic gap in the world.6 In 2016, one percent of the richest people own almost half (49 percent) of the total wealth in the population.7

In addition, corruption cases in a country with Muslims majority are rapidly under control.8 Corruption Watch shows that over the past five years, there has been no significant improvement on corruption eradication in Indonesia. In 2016, the score of Corruption Perceptions Index (CPI) Indonesia is 37. It ranks on 90 among 176 countries measured. Indonesia's score is increased one point and it is dropped two ranks from the previous year. However, Indonesia Corruption Perceptions Index score (IPK) in 2016 is still below Malaysia with 49 scores, Brunei 58 score, and Singapore 85 score. Transparency International ranked ICP rankings as many as 168 countries around the world, with a score of 0 for the most corrupt countries, and 100 for the cleanest. The most important point should be understood that the average score in the world is 43 . It means that all countries with scores below the average are considered corrupt. 9

\footnotetext{
${ }^{6}$ This gap affects poverty in the lower level. Poverty in the lower level is caused by the limitation in doing various acts of corruption. However, they will do corruption if they have the chances of their boss who have low ethics and morality. Purbayu Budi Santosa, "KorupsiBangkrutkanNasionalisme," JurnalDinamikaEkonomi Pembangunan,Vol 1, No, 2011, h. 62.

7DewiRinaCahyani, "Survei: Harta 4 Orang TerkayaSetara 100 Juta Orang Miskin," https://bisnis.tempo.co/read/849439/survei-harta-4-orang-terkaya-setara-100-jutaorang-miskin\#rTSMR55Qm715bIq0.99.

${ }^{8}$ However, it should be understood that the high or low levels of corruption are not merely related to religion, but it is rather related to a clear and firm legal order supported by law enforcement against the corruption. Lihat, Atiqullah, "Sistem Pendidikan Keagamaan Anti Korupsi," Jurnal Karsa, Vol. XVII, No. 1, 2010, h. 79.

9Fana Suparman, "Peringkat Indeks Persepsi Korupsi Indonesia 2016 Turun," http://www.beritasatu.com/hukum/411045-peringkat-indeks-persepsi-korupsiIndonesia-2016-turun.html.
} 
In fact, corruption practices that arise in recent times are very troubling. The results of OTT (caught in the act) done by Corruption Eradication Commission (KPK) in 2017 to a number of regional leaders and state officials become the authentic evidence. There are at least seven region leaders caught in the act, such as Bengkulu Governor Ridwan Mukti, Pamekasan regent Achmad Syafii, Tegal Mayor Siti Masitha, Batubara OK Regent Arya Zulkarnaen, Mayor of Batu Eddy Rumpoko, Kutai Kartanegara Regent (Kukar) Rita Widyasari, and Mayor of Cilegon Tubagus Iman Ariyadi..10 Ironically, from 2004 to June 2017, KPK statistics write that there are 78 district leaders dealing with KPK. It consists of 18 governors and 60 mayors or regents and deputies.11 Unfortunately, by this result, KPK gets bullying by a number of parties.12

The case of corrosive chemicals to KPK investigator named Novel Baswedan some times ago is an authentic proof of corruptors' power in Indonesia. Precisely, on Tuesday, April 11, 2017, at about 5:10 AM, he was doused by corrosive chemicals in front of his house by two unknown people after finishing the Shubuh prayer.13 This case implicitly shows that they-the corruptors-can do anything if they feel annoyed. The values of humanity and civilization are destroyed by the perpetrator and the intellectual actor behind them.14

\footnotetext{
10Anonim, "7 Kepala Daerah Dijerat KPK Selama 2017, TeranyarBupatiCantik yang GemarUndangMusikCadas," ～http://www.tribunnews.com/nasional/2017/09/26/7kepala-daerah-dijerat-kpk-selama-2017-teranyar-bupati-cantik-yang-gemar-undangmusik-cadas.

11Read, http://nasional.kompas.com/read/2017/09/19/07000031/hinggaseptember-2017-5-kepala-daerah-terjaring-ott-kpk-siapa-saja-mereka?page=all.

12Ironically, Commission III of the House of Representatives questioned the OTT in formal juridical. Commission III of the House of Representatives (DPR RI) for two days spelled out KPK (11-12 / 9/17). In a meeting on Tuesday (12/9/2017), Commission III still held the problem of OTT (caught in the act) which increasingly intensified by KPK to arrest the government leaders in various regions, as well as law enforcers (prosecutors and judges). See, Timyadi, "Dua Hari Komisi III DPR Cecar KPK, OTT Dipermasalahkan," http://poskotanews.com/2017/09/12/dua-hari-komisi-iii-dpr-cecar-kpk-ottdipermasalahkan/

${ }^{13 R e a d, ~ D w i ~ A n d a y a n i, ~ “ A p a ~ K a b a r ~ K a s u s ~ N o v e l ~ B a s w e d a n ? ~ I n i ~ J a w a b a n ~ K a p o l r i, " ~}$ https://news.detik.com/berita/3494062/apa-kabar-kasus-novel-baswedan-ini-jawabankapolri.

${ }^{14}$ Mukodi dan Afid Burhanuddin, "Konsep Pembelajaran Anti Korupsi Melalui Teenager Corruption Watch (TCW): Sebuah Upaya Pencegahan Korupsi Sejak Dini Di Sekolah" the paper was presented in national seminar of Dosen Aswaja Nusantara
} 
Looking at the three problems above, the question then arises "What is wrong with Indonesia"? Does not Indonesia agree to the slogan unity in diversity (Bhineka Tunggal Ika)? Why should be frictions between the identity of the religion and diversity? What is wrong with education (Islamic education) and social transformation in Indonesia that makes wealth inequality not proportional? Is not Islam a religion of the majority in Indonesia, but why corruption is rampant? Those question series, certainly are difficult to answer because there are many dimensions and disciplines that encompass it.

In this context, this article will focus on Islamic education and social transformation. Teenager Corruption Watch modeling, abbreviated as TCW, in Islamic schools will be served as its critical dimension. This focuses on three main reasons, namely: (1) Islamic education can achieve good values of individual and social; (2) individual and social good values directly affect the realization of social transformation; (3) TCW becomes the construction of anti-corruption education modeling, while simultaneously realizing the values of Islamic education in Islamic schools.

This research uses descriptive qualitative survey method. The data interpretations are based on qualitative data. The data are related to Islamic education, social transformation, and modeling of anti-corruption education. The data are collected in two Islamic schools in Pacitan district, namely Madrasah Aliyah Negeri (MAN) Pacitan and MTs 06 Ma'arif Mantren. Then, data are analyzed by using qualitative interpretation.

\section{Islamic Education and Social Transformation}

The term Islamic transformation has been popularized by Moeslim Abdurrahman. He states that Islamic transformation is Islam that makes a distinction through the process of modernization or modernity by connecting theological reflection and considering the society's construct in order to generate social transformation movements.15

Association by the theme "Menyemai Militansi Akademisi, Berbasis Keilmuan Aswaja AnNahdliyyah," Universitas Islam Malang, 17-18 Mei 2017, h. 255.

${ }^{15}$ Moeslim Abdurrahman, Islam Sebagai Kritik Sosial. (Jakarta: Erlangga, 2003), h. 186. 
Meanwhile, Islamic education and social transformation have the tight relationship. One and the other cannot be separated. Islamic education leads the people to have the ability to read the "signs" of God, both in the Holy Quran (qauliyyah verses) and in the universe (kauniyyah verses). It is aimed that human beings have the ability to build a dialogical synergy between science and religion. The Qur'an and science must always be related each other to face the people reality with all its dynamics and the reality of nature with all its symptoms.16

Meanwhile, social transformation puts the process of structure changing, social system, and culture in society. Therefore, the transformation is defined as a social structure changing or structure renewal. In addition, it is also defined as the process of value change. The word transformation derives from the English word transform that means to control a form to another form17. Thus, Islamic education and social transformation is a unity of ideas and concepts that have the same vision, to realize the obedience, civilization, and empowerment.

The marriage, between Islamic education and social transformation, rises the idea of transformative Islamic education. The transformative Islamic education here is an education that equips the learners (human beings) to have a set of Islamic skills constructed from theological reflection based on the socio-cultural realities towards self-change enlightenment. However, in its implementation, transformative Islamic education is constrained by various problems.

\section{The Problems of Transformative Islamic Education}

Reason (ratio) and senses are two tools of knowledge. The first paradigm will bring about rationalism, while the second paradigm will lead the people to sensualism, empiricism, materialism, and positivism. The first object is abstract and its paradigm is logical. Then the second object is empirical and its paradigm is science. These two paradigms ultimately reject supra-logical and non-empirical mystical objects. These

${ }^{16}$ Askar, "Misi Propetik Pendidikan Islam: Membentuk Karakter Menuju Transformasi Sosial Membangun Peradaban," Jurnal Hunafa: Jurnal Studia Islamika, Vol. 8, No. 1, 2011, h. 
two tools of knowledge then firmly refuse to give a significant role in the development of science and technology in the West.17

The two tools of knowledge mentioned above, then bring up a variety of discourses on the knowledge object, as well as Islamic knowledge. Moreover, both of them bring up new disciplines completed with the scientific problems that surround them. Problems of ontology, epistemology, and axiology of Islamic education (transformative) are some of the examples. More details of these problems will be revealed in the following discussion.

\section{Ontology Problem}

The object study of Islamic education always derives from the Islamic normative foundation from al-Qur'an (qauliyah) through the soul experience of Prophet Muhammad SAW that later called as revelation, then submitted to all people and the universe (kauniyah). Both these foundations are then developed and studied to create universal educational concepts and theories. Furthermore, those universal theories and concepts are studied through the activities of experiment and scientific research. Later, it will create theories or science of Islamic Education. Those theories are described operationally to be developed into Islamic education methods, curricula, and techniques.18

Moreover, the problems of Islamic education (transformative) are always ontologically departed from the problems that exist within the area of Islamic studies itself. Borrowing the categorization of Muhaimin, the problems of Islamic studies are categorized into three. They are (1) foundational problems, which consists of the basic problems, the foundation of religion and the problem of empirical philosophical foundation; (2) structural problems, which derives from the demographic and geographic structure, the structure development of the human soul, as well as the economic and educational structures; and (3) operational problem. In micro areas, it will be associated with various components of Islamic education. In addition, in macro areas, it is related to the

\footnotetext{
17Imam Hanafi, "Basis Epistemologi dalam Pendidikan Islam," Jurnal Pendidikan Islam, Vol. 1, No. 1, 2012, h. 19-30.

${ }^{18}$ Moh. Wardi, "Problematika Pendidikan Islam dan Solusi Alternatifnya: Perspektif Ontologis, Epistemologis dan Aksiologis," Jurnal Tadrîs, Vol. 8, No. 1, 2013, h. 56-57.
} 
relevance of Islamic education with social systems, political, economic, cultural and religious. Viewed from demographic and geographical structures, it can be categorized into towns, suburbs, villages and remote villages.19

Therefore, ontologically, the greatest problem of transformative Islamic education actually arises from within itself, while the problem that comes from outside more results as the impact of the Islamic education weaknesses itself. The Islamic education weakness is actually as same as the Muslim weaknesses. In fact, according to Syafi'i Ma'arif, the internal vulnerability of Muslims can threaten the destruction of the world's Islamic countries.20 Therefore, this is very dangerous to Islamic world life and civilization.

\section{Epistemology Problem}

Discussed on the epistemology problematic in Islamic education also reveal the essence of Islamic education epistemology itself. Literally, Islamic educational epistemology is a discipline that discusses how to get object knowledge of Islamic education. The main point of Islamic education epistemology essentially lies on how to gain knowledge.

The problem of Islamic education epistemology can be classified into three main problems. They are (1) differences of understanding in Islamic knowledge even though the people learn it in the same source, time and place; (2) differences in interpretation in learning of Islamic knowledge. This is due to differences in understanding Islamic knowledge acquired; (3) differences in the application of Islamic knowledge acquired. The difference of understanding and interpretation related to Islamic knowledge became the point of conflicts that result in the difference of Islamic knowledge application.

\section{Axiology Problem}

${ }_{19}$ Muhaimin, Pemikiran dan Aktualisasi Pengembangan Pendidikan Islam (Jakarta: Rajawali Pers, 2011), h. 45.

${ }^{20}$ Agung Sasongko, "Syafii Ma'arif: Kerapuhan Internal Ancam Dunia Islam," Republika, Kamis, 16 April 2015. 
Axiology is a study that investigates the nature of values, generally viewed from philosophical views. The axiology problem of Islamic educational that arose at the grass root lately is the result of the decreased meaning of Islamic education itself. The people understanding related to Islamic education in term of ontology and epistemology are not implemented massively in axiology term. It means that Islamic education is just a knowledge and understanding itself. As the example, doing corruption,21 stealing, bullying and doing anarchism are categorized as criminals that everyone understands it. But, practically, the people still do these crimes even though they know the riks. In other words, many people are only putting religious and Islamic knowledge as knowledge itself without implementing in real practices. Unfortunately, there are only a few people who make religion and Islamic values as an anticipatory strategy to face the challenges of life in the future.

Therefore, nowadays, it is assumed that Muslim knowledge tradition is difficult in responding, anticipating the needs and challenges of lives, even less manipulating and contributing to the consolidation of an egalitarian, democratic and humanist civilization of humanity. The assumption stating that Muslim traditions tend to be unresponsive is supported by two traditions and orientations of the theologicalnormative and deductive, legalistic pattern of Muslim thought. The theological-normative mindset separates the concept of God from the world of reality. All the discussion about God seems to be eschatological. God is real, but God's justice is done in the afterlife, not in the reality. God's justice is understood as the metaphysical thing, it is not actually in social life. Therefore, it arises the assumption that everything will only get revenge of merit or sin in the afterlife, while the result of actions in this world is solely caused by the law of nature. This theologicalnormative thinking orientation explicitly separates life in the real world from the afterlife.22 Therefore, the axiological problem of transformative

\footnotetext{
${ }^{21}$ Corruption is one of thesocial troubles (social pathology). Its existence becomes a parasite in human lives. Nurul Yaqin, "Program Pendidikan Anti Korupsi Di Madrasah," Jurnal Islamuna, Vol. 2, No. 2, 2015, h. 267.

${ }^{22}$ Abd. Rachman Assegaf, "Reorientasi Tradisi Keilmuan Pendidikan Islam dalam Perspektif Hadharah Al-'Ilm," dalam In N. A. \& Sumedi (ed.), Antologi Pendidikan Islam, (Yogyakarta: Program Pasca Sarjana UIN Sunan Kalijaga, 2010), h. 254.
} 
Islamic education is the weaknesses of its value and the weaknesses of its implementation in real practices.

Despite some weaknesses, transformative Islamic education conceptually has become a supporting model for anti-corruption education in schooling level. It is based on the core of transformative Islamic education that equips the learners to have a set of Islamic skills constructed from theological reflection based on socio-cultural realities. Moreover, transformative Islamic education values emphasize the implementation of Islamic knowledge in real life. In this area, transformative Islamic education can synergize significantly through the application of TCW modeling concepts in schools. That is, Islamic insight (Islamic transformative) is placed as a supporting tool, as well as an instrument of the actions' value.

\section{Modeling of Teenager Corruption Watch (TCW) in Islamic Schools}

Stopping corruption in Indonesia needs serious efforts. It covers a multidisciplinary approach, a touch of religion,23 a systematic and simultaneous way. Moreover, corruptors are generally those who have high formal education, starting from scholar level to doctoral degree even professors. Therefore, the efforts that can be done to prevent corruption are started at the early age of students, both in formal and non-formal education. Teenager Corruption Watch (TCW) models in formal schools can be practiced.

Teenager Corruption Watch (TCW) is a group of children who monitor the corruption issues. In another word, TCW is attributed as an organization to eliminate corruption in schools, like mini KPKs in schools. The existence of TCW in schools can be a place for anti rashuwah organizations, both in the extracurricular organization and extracurricular. The goal is to strengthen the understanding for learners

\footnotetext{
${ }^{23}$ There is no single religion in the world that justifies corruption practices, especially Islam. In an Islamic perspective, corruption is at least categorized into seven terms. The six terms are mentioned specifically, such ad gulul, al-suht, harb, al-sariqah, al-dalwu, and gasab. However, there is a term that does not specifically indicate to the meaning of corruption, but based on another verse, it has the similar meaning as corruption. This term is called as al-itsm, makr, khabais, and dakhal. Read, Muh. Mustakim, "Wawasan AlQuran Tentang Pendidikan Anti Korupsi," Jurnal At-Tajdid, Vol. 2, No. 1, 2013, h. 80.
} 
that corruption is harmful to themselves and other people. TCW members act like KPK. They provide education to other students related to the prevention of corruption early.24 Through TCW organizations, learners will be equipped with these values. In the future, students will have anti-corruption character.

Islamic School (Islamic Education Institute) can be used as modeling incubator. Selection of Islamic schools as pilot project, as well as modeling, is based on four reasons: (1) the proportional content of Islamic school curriculum in Islamic educational is 70\%:40\%; (2) Islamic schools emphasize moral values rather than public schools; (3) the educators have better understand in Islamic values than those in public schools; (4) Islamic school environment is more supportive than public schools environment.25

Early corruption prevention through TCW program at the school is an appropriate step. Early character building and early awareness are required to minimize the issue of corruption. TCW is an organization that focuses on educating, monitoring, and supervising the acts of corruption in schools. Nine anti-corruption values become the basis for implementing their actions, such as (1) honesty, (2) caring, (3) independence, (4) discipline, (5) responsibility, (6) hard work, (7) simplicity, (8) courage, and (9) justice.26 By borrowing the term from Fuad Hassan, the nine values will be used as a process of building the Islamic culture in school.27 Building Islamic culture in schools is one of the important instruments in succeeding anti-corruption education.28

\footnotetext{
${ }^{24}$ Mukodi dan Afid Burhanuddin, "Konsep Pembelajaran Anti Korupsi Melalui Teenager Corruption Watch (TCW): Sebuah Upaya Pencegahan Korupsi Sejak Dini Di Sekolah" makalah dipresentasikan dalam Seminar Nasional Asosiasi Dosen Aswaja Nusantara dengan tema "Menyemai Militansi Akademisi, Berbasis Keilmuan Aswaja AnNahdliyyah," Universitas Islam Malang, 17-18 Mei 2017, h. 259.

${ }^{25}$ See, the reality in the school surrounding.

${ }^{26}$ Mukodi dan Afid Burhanuddin, "Anti-Corruption Education Based On Triadic Center Of Education," the paper was presented in International Conference on Education and Science (ICONS 2017) by the theme "Character Development in the 21st Century Education," Universitas PGRI Yogyakarta, Kamis, 20 Juli 2017, h. 89.

27Fuad Hassan, Pendidikan adalah Pembudayaan: dalam Pendidikan Manusia Indonesia, (Jakarta: Penerbit Kompas, 2004), 10.

${ }^{28}$ Harmanto, "Pendidikan Antikorupsi Melalui Budaya Sekolah Berbasis Nilai-Nilai Keislaman," Jurnal Islamica, Vol. 7, No. 1, 2012, h. 101-119.
} 
TCW provides an opportunity for the learners to play the role directly into the actual issues related to the value. The goal is educating the learners to be fortified from actions that lead to corruption.29 Therefore, the learners are able to recognize and practice directly the nine values mentioned above through real experience. The success of corruption eradication does not only based on law enforcement process but also determined by the prevention. It implies that corruption can be stopped early by strengthening anti-corruption education in every school.

It is important because the term anti-corruption education is not stated in Law No. 20 of 2003 on National Education System. Therefore, all anti-corruption education efforts are seen as the result of educational innovation, such as TCW Program. TCW is the implementation of anticorruption curriculum innovation. Because the education purpose based on the education system is developing the ability and building the character and nation civilization in order to educate the nation's life.

According to Mukodi \& Afid Burhanuddin, anti-corruption education is an early prevention that has a good impact in limiting corruption. Unlike the repressive approach, this preventive approach cannot be seen directly. The results can be seen over a long period. Meanwhile, repressive action through law enforcement seems aggressive in prosecuting and imprisoning corruptors. Anti-corruption education is an effort to prevent corruption in Indonesia. Indeed, there is no specific answer why the corruption problem is spread massively in a country. However, anti-corruption education is not based on a specific scientific perspective, but it is based on the problems phenomenon and cultural approaches. 30

${ }^{29}$ Mukodi dan Afid Burhanuddin, "Konsep Pembelajaran Anti Korupsi Melalui Teenager Corruption Watch (TCW): Sebuah Upaya Pencegahan Korupsi Sejak Dini Di Sekolah" the paper was presented in national seminar of Dosen Aswaja Nusantara Association by the theme "Menyemai Militansi Akademisi, Berbasis Keilmuan Aswaja AnNahdliyyah," Universitas Islam Malang, 17-18 Mei 2017, h. 259.

30Mukodi dan Afid Burhanuddin, "Konsep Pembelajaran Anti Korupsi Melalui Teenager Corruption Watch (TCW): Sebuah Upaya Pencegahan Korupsi Sejak Dini Di Sekolah" the paper was presented in national seminar of Dosen Aswaja Nusantara Association by the theme "Menyemai Militansi Akademisi, Berbasis Keilmuan Aswaja AnNahdliyyah," Universitas Islam Malang, 17-18 Mei 2017, h. 259. 
In this context, the people involved in TCW are not only the learners, but also the principals, teachers, and school employees. Certainly, all of the parties have different roles. The principal acts as a protector as well as an organizational advisor. Teachers are acted as mentors. Therefore, the teachers control and help to solve organization's problems. Staff or school employees act as supporting elements. Meanwhile, as a subject, learners have a role to run the organization well. Each student has a different task.

\section{The Course of Anti-Corruption Education Modeling in Pacitan Islamic School}

Anti-corruption education modeling in Pacitan Islamic school is implemented in two schools: MTs Ma'arif 06 Mantren as the junior high school level and Madrasah Aliyah Negeri Pacitan as the senior high school level. The numbers of respondents were 83 students, covering 28 respondents from MTs Ma'arif 06 Mantren Pacitan and 55 from MAN Pacitan. It consists of 36 male and 47 female. The result in both Islamic schools, related to the corruption perception, awareness of corruption, and modeling of anti-corruption education shows positive significant value. Quantitatively, from 22 questions raised, as well as the results of deep interviews related to corruption and modeling shows a positive number. Furthermore, it can be explained in detail below.

\section{Learners Perception toward Corruption}

When the learner is asked a question about the understanding level of corruption, 79\% respondents answered that they understand well. There are only $29 \%$ respondents who answered did not understand and less understood about corruption. Moreover, respondents also state that corruption is a form of fraud or misuse of state money for personal gain or a particular group of people. In percentage, $90 \%$ of respondents understand well about corruption fraud. The rest, only $10 \%$ of respondents say quite understand, less understand and did not understand toward corruption fraud. See more on the following 1 and 2 pictures:

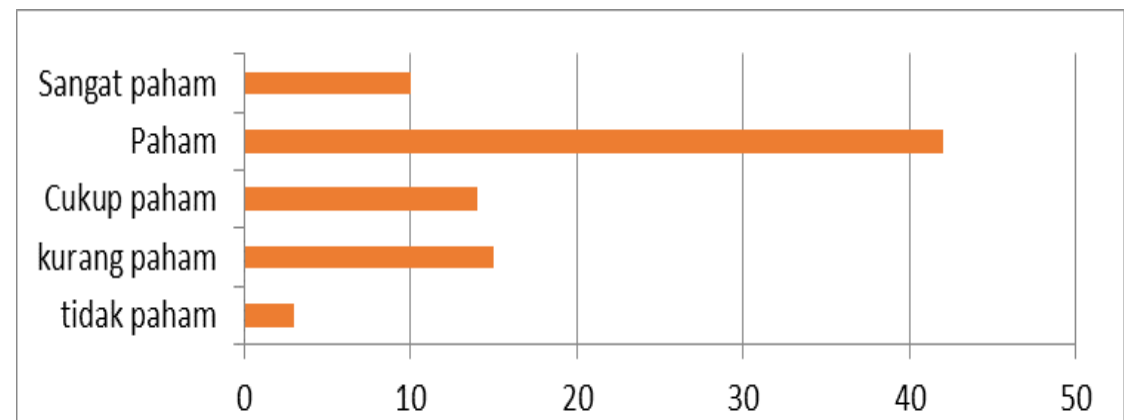


Figure 1.

The Respondent's Perception of Corruption

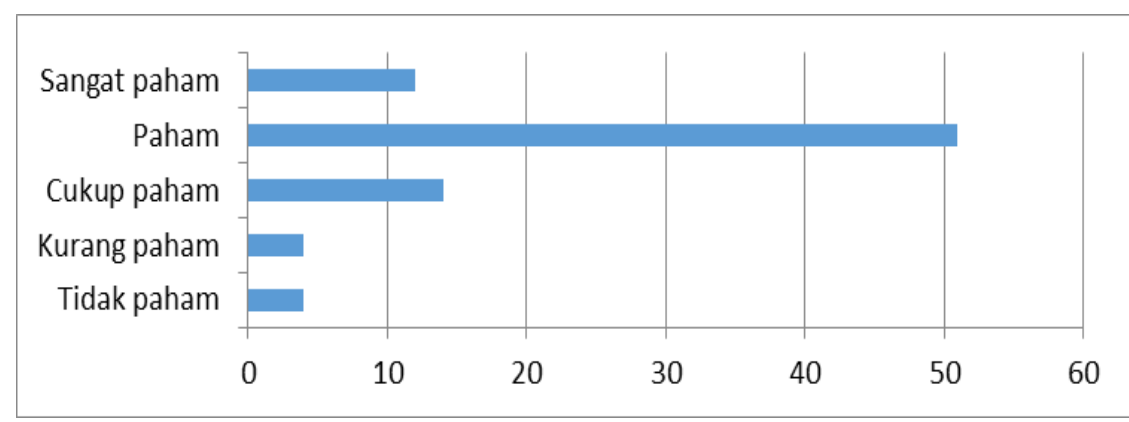

Figure 2.

The Respondent's Understanding Level toward Corruption Fraud

What is shown in figures 1 and 2 above is the answer to the respondents' perceptions and understanding about corruption practices occurred lately. In this case, the most important point to be understood is that the respondents are aware of corruption's dangers and its negative effects. This answer was confirmed from the interviews obtained. The majority of learners who become respondents say that they understand very well about corruption and its negative effects. In fact, they provide concrete solutions to small corruption practices in schools. Here is a transcript of the interview:

... corruption is better removed in our lives, because education does not tell about corruption ... (R1). ... it is better that corruption should be dealt early because it gives dangers to others ... (R2). ..the corruption practices have to be handled early, especially for the teachers, they have 
to divide the money aid (from the government) for the poor students directly without dividing evenly to all the students in schools. (R3).

Unfortunately, the real implementation in the field is different from the theories. Many learners who have the understanding of corruption, impact, and consequences continue to do corruptive actions in small practices, such as lying, cheating, and being indiscipline.

\section{The Learners' Motivation in Eradicating Corruption}

Motivation to prevent corruption acts in everyday life, whether at home, school or community, is expressed by the learners through showing their concern for corruption practices. As a result, $91 \%$ of respondents say that they are highly motivated to participate in corruption eradication. Only $9 \%$ of respondents say that they are not motivated to participate in the action.

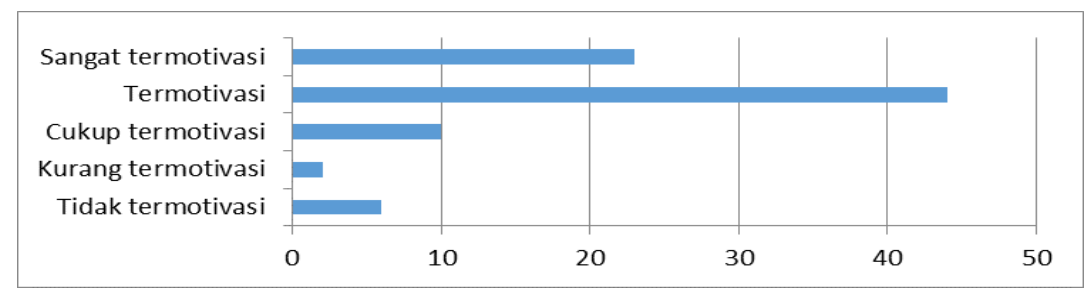

Figure 3.

The Learners' Motivation in Eradicating Corruption

Figure 3 above shows the high level of respondents motivation in joining corruption eradication actions. Moreover, when the respondents are asked to the question "how much they are motivated to prevent corruption acts in everyday life", $82 \%$ of respondents say that they are motivated. It implies that the younger generation of junior and senior high school in Pacitan have strong concern and willingness to prevent corruption. This can be fresh air as well as the hope for the prevention of corruption in the future.

\section{Modeling of Anti-Corruption Education in School}

Most of the respondents expect an early anti-corruption model of awareness in school. In fact, they have positive response toward the implementation of TCW. The result shows that there are $87 \%$ of 
respondents say agree on it, while there are $23 \%$ of respondents say less agree. This can be seen clearly in Figure 4 below:

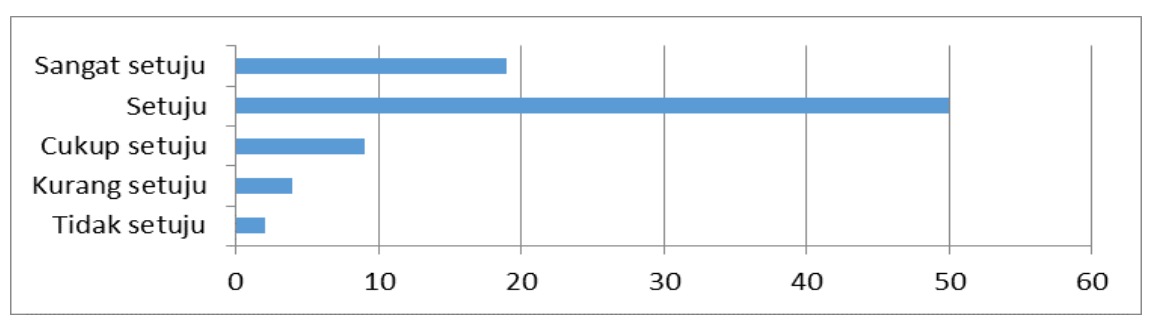

Figure 4.

Modeling of Anti-Corruption Education through TCW

There are at least three alternative TCW models that can be implemented in schools, especially in Islamic educational institutions. They are (1) extracurricular TCW (2) intra-curricular TCW (3) Applicative TCW. All of three models above have their own function and roadmap. First, Extracurricular TCW is a TCW model formed in the form of extracurricular. That is, the learners do not have an obligation to follow this activity. The learners can join this model voluntarily. Extracurricular TCW is like scouts organization, PMR (Red Cross Youth), Rohis (Rahani Islam) etc. This TCW model can be seen in figure 5 below:

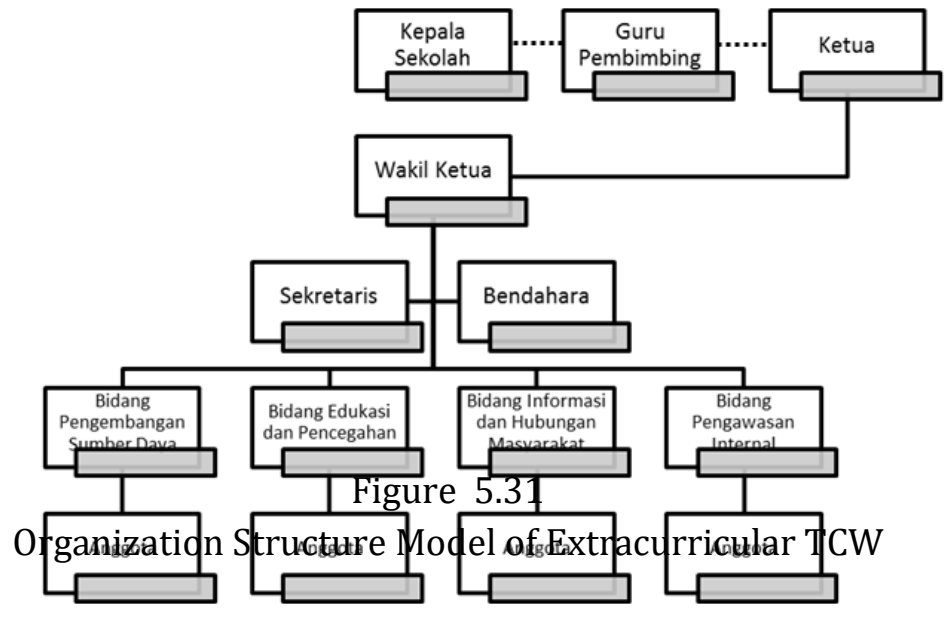

${ }^{31}$ Mukodi dan Afid Burhanuddin, "Konsep Pembelajaran Anti Korupsi Melalui Teenager Corruption Watch (TCW): Sebuah Upaya Pencegahan Korupsi Sejak Dini Di Sekolah" the paper was presented in national seminar of Dosen Aswaja Nusantara Association by the theme "Menyemai Militansi Akademisi, Berbasis Keilmuan Aswaja AnNahdliyyah," Universitas Islam Malang, 17-18 Mei 2017, h. 259. 
The structure in figure 5 above is a prototype of Extracurricular TCW model, where there is a role as chairperson, secretary, treasurer, head of the field, up to members of the field. There are four areas in TCW, namely: (1) Human Resource Development Division, (2) Education and Prevention, (3) Information and Public Affairs Sector, and (4) Internal Control.32 The Extracurricular TCW model activities rely on an attempt to habituate good practices based on Islamic values and social norms. In addition, it is served as a vehicle for socialization anti-corruption education in school daily lives. Thus, learners will have knowledge and understanding of corruption and its impact. As a result, they have anticorruption behaviors and awareness in preventing corruption acts.

The second model is intra-curricular TCW. This TCW model is formed by the school and the learners have to join this model. This is like the existence of OSIS (Intra-School Student Organization) at school. The scheme of this model can be described in the following figure 6:

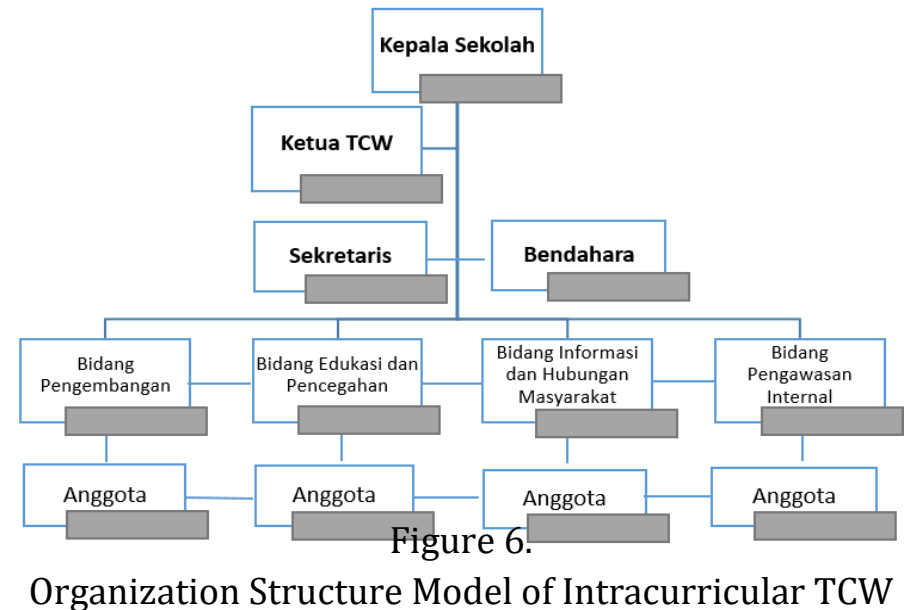

Figure 6 above is organizational of intra-curricular TCW model structures in schools. Even though, the model can vary from school to school. The most important point in this model is the coordinated lines are established, developed, and issued by the school. In other words, the

\footnotetext{
${ }^{32}$ Mukodi dan Afid Burhanuddin, "Konsep Pembelajaran Anti Korupsi Melalui Teenager Corruption Watch (TCW): Sebuah Upaya Pencegahan Korupsi Sejak Dini Di Sekolah" the paper was presented in national seminar of Dosen Aswaja Nusantara Association by the theme "Menyemai Militansi Akademisi, Berbasis Keilmuan Aswaja AnNahdliyyah," Universitas Islam Malang, 17-18 Mei 2017, h. 259.
} 
learners must follow this organization. The organization management comes from the students in each class. These extracurricular TCW programs contain religious values, ethics, morals, social norms, and good practices.

Third is Applicative TCW. This model is essentially a top-down model. It covers from superiors level to subordinates. The scheme can be directly formed as one of the work programs commanded by the Education Department and then instructed to be implemented by the Education Unit. Thus, this Applicative TCW model is a by design model from the ruler. Therefore, there must be good will from the relevant stakeholders, such as Head of the district, Head of Department, Head of UPT, Schools Principals, and school members inside. This third scheme model can be run well if it was supported by top-level officials. However, without supporting efforts from the top parties, this model will be failed.

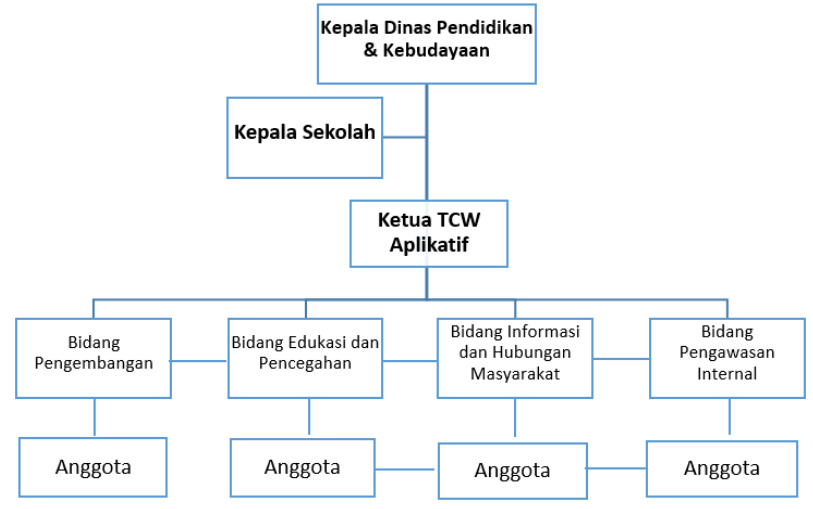

Figure 7.

Organization Structure Model of Applicative TCW

Those three TCW models mentioned above principally can be used as one model of anti-corruption education in schools. certainly, each model has strengths and weaknesses. Therefore, the school can choose the most effective scheme model, based on the specialty and local wisdom of each region. Anti-corruption education materials in schools that are used as discussion and socialization materials in the implementation of each TCW model include, (1) Islamic religious values; (2) social ethics and norms; (3) socialization of legal issues; (4) examples of good and bad behavior; (5) the existence of Kantin Kejujuran; (6) socialization of anti-cheating. See figure 8 below: 


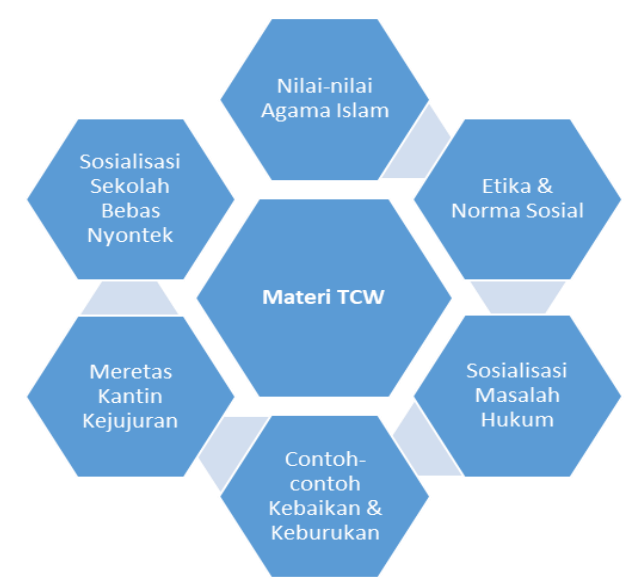

Gambar 8.

TCW Materials in Islamic School

Figure 8 above points out that the alternative material offered is just one example of TCW material implemented in the school. However, the school can develop and enrich the scope of the material related to the needs of each school. Anti-corruption education applicative strategies via digital can also be practiced in schools, such as: (1) presenting anticorruption online games; (2) creating cartoons and caricature by the theme of anti-corruption resistance; (3) disseminating anti-corruption issues on the internet; (4) giving cyber anti-corruption advertisements; (5) posting the photos of corruptors via digital.33 Certainly, the five strategies above must be based on Islamic values. By doing so, the school can become an effective and efficient anti-corruption education media.

\section{Conclusion}

Corruption is a common enemy to be eradicated and destroyed, wherever and wherever it grows. One way is through the TCW model in Islamic schools. It is implemented through civilizing the Islamic religious values; social ethics and norms; socialization of legal issues; examples of good and bad behavior; the existence of Kantin Kejujuran, socialization of

${ }^{33}$ Mukodi dan Afid Burhanuddin, "Anti-Corruption Education Based On Triadic Center Of Education," the paper was presented in International Conference on Education and Science (ICONS 2017) by the theme "Character Development in the 21st Century Education," Universitas PGRI Yogyakarta, Kamis, 20 Juli 2017, h. 90. 
anti-cheating. Islamic education (transformative) becomes the basis for TCW implementation. Therefore, it has the strength as well as Ilahiyah power to destroy the corruptions.

\section{Bibliografi}

Abdurrahman, Moeslim, Islam Sebagai Kritik Sosial, Jakarta: Erlangga, 2003.

Andryanto, Dian, "Ahok Dihukum Dua Tahun, Putusan Hakim Bulat," https://nasional.tempo.co/read/873676/ahok-dihukum-dua-tahunputusan-hakim-bulat.

Anonim, "Kelas Menengah Di Indonesia Mencapai 170 Juta Pada Tahun 2015," http://kbriseoul.kr/kbriseoul/index.php/id/2013-01-21-22-49-

05/berita-terkini/419-kelas-menengah-di-indonesia-mencapai-170-jutapada-tahun-2015.

Andayani, Dwi, "Apa Kabar Kasus Novel Baswedan? Ini Jawaban Kapolri," https://news.detik.com/berita/3494062/apa-kabar-kasus-novelbaswedan-ini-jawaban-kapolri.

Anonim, "7 Kepala Daerah Dijerat KPK Selama 2017, Teranyar Bupati Cantik yang Gemar Undang Musik Cadas," http://www.tribunnews.com/nasional/2017/09/26/7-kepala-daerahdijerat-kpk-selama-2017-teranyar-bupati-cantik-yang-gemar-undangmusik-cadas.

Askar, "Misi Propetik Pendidikan Islam: Membentuk Karakter Menuju Transformasi Sosial Membangun Peradaban," Jurnal Hunafa: Jurnal Studia Islamika, Vol. 8, No. 1, 2011.

Atiqullah, "Sistem Pendidikan Keagamaan Anti Korupsi," Jurnal Karsa, Vol. XVII, No. 1, 2010.

Azra, Azumardi, "Agama dan Pemberantasan Korupsi", dalam Harmanto, "Pendidikan Antikorupsi Melalui Budaya Sekolah Berbasis Nilai-Nilai Keislaman," Jurnal Islamica, Vol. 7, No. 1, 2012.

B. Santosa, Purbayu, "Korupsi Bangkrutkan Nasionalisme," Jurnal Dinamika Ekonomi Pembangunan, Vol 1, No, 2011.

Cahyani, Dewi R., "Survei: Harta 4 Orang Terkaya Setara 100 Juta Orang Miskin," https://bisnis.tempo.co/read/849439/survei-harta-4-orang-terkayasetara-100-juta-orang-miskin\#rTSMR55Qm715bIq0.99.

Dewi, Ernita, "Transformasi Sosial dan Nilai Agama" Jurnal Substantia, Vol. 14, 2012. 
Hassan, Fuad, Pendidikan adalah Pembudayaan: dalam Pendidikan Manusia Indonesia, Jakarta: Penerbit Kompas, 2004.

Harmanto, "Pendidikan Antikorupsi Melalui Budaya Sekolah Berbasis Nilai-Nilai Keislaman,” Jurnal Islamica, Vol. 7, No. 1, 2012.

Hanafi, Imam, "Basis Epistemologi dalam Pendidikan Islam," Jurnal Pendidikan Islam, Vol. 1, No. 1, 2012.

Humas, "BPS: Per September 2016, Jumlah Penduduk Miskin Indonesia Berkurang 0,25 Juta," http://setkab.go.id/bps-per-september-2016jumlah-penduduk-miskin-indonesia-bekurang-025-juta/.

Http://nasional.kompas.com/read/2017/09/19/07000031/hingga-september2017-5-kepala-daerah-terjaring-ott-kpk-siapa-saja-mereka?page=all.

Mukodi, A. Burhanuddin, "Konsep Pembelajaran Anti Korupsi Melalui Teenager Corruption Watch (TCW): Sebuah Upaya Pencegahan Korupsi Sejak Dini Di Sekolah" makalah dipresentasikan dalam Seminar Nasional Asosiasi Dosen Aswaja Nusantara dengan tema "Menyemai Militansi Akademisi, Berbasis Keilmuan Aswaja An-Nahdliyyah," Universitas Islam Malang, 17-18 Mei 2017.

Mukodi, A. Burhanuddin, "Anti-Corruption Education Based On Triadic Center Of Education," makalah dipresentasikan dalam International Conference on Education and Science (ICONS 2017) dengan tema "Character Development in the 21st Century Education," Universitas PGRI Yogyakarta, Kamis, 20 Juli 2017.

Muhaimin, Pemikiran dan Aktualisasi Pengembangan Pendidikan Islam, Jakarta: Rajawali Pers, 2011.

Mustakim, Muh, "Wawasan Al-Quran Tentang Pendidikan Anti Korupsi," Jurnal At-Tajdid, Vol. 2, No. 1, 2013.

Penyusun, T, Ringkasan Eksekutif Laporan Kemerdekaan Beragama Berkeyakinan (KBB) Di Indonesia Tahun 2016, Jakarta: Wahid Foundition, 2016.

R. Assegaf, Abd., "Reorientasi Tradisi Keilmuan Pendidikan Islam dalam Perspektif Hadharah Al-'Ilm," dalam In N. A. \& Sumedi (ed.), Antologi Pendidikan Islam, Yogyakarta: Program Pasca Sarjana UIN Sunan Kalijaga, 2010.

Sasongko, Agung, "Syafii Ma'arif: Kerapuhan Internal Ancam Dunia Islam," Republika, Kamis , 16 April 2015. 
Suparman, Fana, "Peringkat Indeks Persepsi Korupsi Indonesia 2016 Turun," http://www.beritasatu.com/hukum/411045-peringkat-indeks-persepsikorupsi-indonesia-2016-turun.html.

Timyadi, "Dua Hari Komisi III DPR Cecar KPK, OTT Dipermasalahkan," http://poskotanews.com/2017/09/12/dua-hari-komisi-iii-dpr-cecar-kpkott-dipermasalahkan/

Wardi, Moh, "Problematika Pendidikan Islam dan Solusi Alternatifnya: Perspektif Ontologis, Epistemologis dan Aksiologis," Jurnal Tadrîs, Vol. 8, No. 1, 2013.

Yaqin, Nurul, "Program Pendidikan Anti Korupsi Di Madrasah,” Jurnal Islamuna, Vol. 2, No. 2, 2015 